\title{
HTLV-1 gene expression by individual infected clones determines susceptibility to lysis by cytotoxic T lymphocytes specific for Tax and HBZ
}

\author{
Aileen G Rowan ${ }^{*}$, Amy McCallin', Heather A Niederer', Silva Hilburn², Lucy Cook', Graham P Taylor², \\ Charles RM Bangham'
}

From 16th International Conference on Human Retroviruses: HTLV and Related Viruses

Montreal, Canada. 26-30 June 2013

Host cytotoxic T-lymphocyte (CTL) responses are critical in limiting expansion of HTLV-1-infected CD4+T-cells in vivo, and most individuals generate abundant Taxspecific CTL. Although Tax is immunodominant, the ability to efficiently present peptides from $\mathrm{HBZ}$ on $\mathrm{MHC}$ class 1 is associated with a lower proviral load and a reduced frequency of HAM/TSP. HBZ mRNA is expressed in vivo, directing proliferation of infected cells. However, HBZ-specific CTL were detectable in fresh PBMCs in only $25 \%$ of chronically infected individuals. We hypothesised that HBZ has evolved to evade the generation of effective HBZ-specific CTLs. To evaluate the selective capacity of a potent HBZ-specific CTL response, we assayed the ability of equally efficient Tax-and HBZspecific CTL clones to kill unstimulated, naturally infected cells from 16 HLA-A*02+HTLV-1+ individuals. Infected cells which expressed Tax during the course of the assay upregulated surface expression of HLA-A*02, and were eliminated efficiently by Tax-specific CTL. HBZ-specific CTL killed Tax+ cells less efficiently, preferentially killing cells with high levels of HLA-A*02. As a proportion of infected cells do not express Tax owing to silencing, mutation or viral integration site (IS) location, we tested whether HBZ-specific CTLs could kill Tax-infected cells, using high-throughput sequencing to monitor survival of infected clones after CTL selection. We are now validating our findings using patient-derived HBZ-specific CTL, and mapping HBZ epitopes recognised in vivo. In conclusion, the efficacy of HBZ-specific CTLs appears to be limited by the level of antigen

* Correspondence: a.rowan@imperial.ac.uk

${ }^{1}$ Section of Immunology, Imperial College London, UK

Full list of author information is available at the end of the article presentation, but may confer the ability to target infected cells which escape Tax-specific CTL.

\section{Authors' details}

${ }^{1}$ Section of Immunology, Imperial College London, UK. ${ }^{2}$ Section of Infectious Diseases, Imperial College London, UK.

Published: 7 January 2014

doi:10.1186/1742-4690-11-S1-O21

Cite this article as: Rowan et al:: HTLV-1 gene expression by individual infected clones determines susceptibility to lysis by cytotoxic

T lymphocytes specific for Tax and HBZ. Retrovirology 2014 11(Suppl 1):O21.
Submit your next manuscript to BioMed Central and take full advantage of:

- Convenient online submission

- Thorough peer review

- No space constraints or color figure charges

- Immediate publication on acceptance

- Inclusion in PubMed, CAS, Scopus and Google Scholar

- Research which is freely available for redistribution

Submit your manuscript at www.biomedcentral.com/submit
() Biomed Central 